Article

\title{
An Analysis of the Determinants of Entrepreneurial Intentions among Students: A Romanian Case Study
}

\author{
Cristian C. Popescu ${ }^{1}$, Ionel Bostan ${ }^{2, *}$, Ioan-Bogdan Robu ${ }^{3}$, Andrei Maxim ${ }^{4}$ \\ and Laura Diaconu (Maxim) ${ }^{5}$ \\ 1 Department of Economics and International Relations, Faculty of Economics and Business Administration, \\ "Alexandru Ioan Cuza" University of Iasi, Iasi 700505, Romania; cristiancpopescu@yahoo.com \\ 2 Doctoral School of Economics, "Stefan cel Mare" University of Suceava, Suceava 720229, Romania \\ 3 Department of Accounting, Economic Informatics and Statistics, Faculty of Economics and Business \\ Administration, “Alexandru Ioan Cuza” University of Iasi, Iasi 700505, Romania; bogdan.robu@feaa.uaic.ro \\ 4 Department of Management, Marketing and Business Administration, Faculty of Economics and Business \\ Administration, "Alexandru Ioan Cuza" University of Iasi, Iasi 700505, Romania; andrei.maxim@feaa.uaic.ro \\ 5 Department of Economics and International Relations, Faculty of Economics and Business Administration, \\ "Alexandru Ioan Cuza" University of Iasi, Iasi 700505, Romania; lauradiaconu_07@yahoo.com \\ * Correspondence: ionel_bostan@yahoo.com; Tel.: +40-0230-216-147
}

Academic Editor: Marc A. Rosen

Received: 9 May 2016; Accepted: 30 July 2016; Published: 9 August 2016

\begin{abstract}
Developing people's interest towards starting a business plays a vital role in the former socialist countries in which, for a very long time, private property and free initiative were almost completely annihilated. Therefore, countries like Romania cannot design a sustainable growth model without taking into account the necessary improvements in the human capital factor, through the entrepreneurial education specific to the market economy, and in the social capital, which leads to stability and enhances the economic activity. The main objectives of this paper are to analyze how much the entrepreneurial intentions are influenced by certain psycho-behavioral traits of the individual (creativity, locus of control, need for achievement and risk taking propensity) and to evaluate the influence of different types of education on these intentions, in order to see if the entrepreneurial education significantly influences the entrepreneurial intentions of Romanian young people. By analyzing the specialized literature, we have developed six research hypothesis that were tested on a sample of 600 students from the undergraduate (bachelor) and master programs within the large state universities of Romania who have entrepreneurship courses in the content of their curricula, with the help of a questionnaire-based survey. Depending on the research hypothesis, several data analysis approaches were used, including Analysis of Variance (ANOVA), Principal Component Analysis (PCA) and General Linear Models (GLM). The main results of this study clearly illustrate that the need for achievement and the propensity towards taking risks play an important role in determining the entrepreneurial intention. Furthermore, graduates of the high schools with an entrepreneurial field are less inclined to engage in businesses compared to the graduates of the high schools that offer general education.
\end{abstract}

Keywords: sustainability; creativity; locus of control; need for achievement; risk taking propensity; types of education; Analysis of Variance (ANOVA); Principal Component Analysis (PCA); General Linear Models (GLM); entrepreneurship/good way to self-realization; enhancing the imagination

\section{Introduction}

The development of a market economy relies on stimulating the entrepreneurial spirit. Capitalism is known for its enhancing effects in the case of those who want and are able to achieve their goals. As these individuals are not few, sometimes, some favorable features, circumstances or certain stimuli 
make the difference. Naturally, when a certain level of social position and income was reached, individual achievement is the most important of these favorable factors. However, we cannot neglect the importance of the individual's capacity of taking risks or the possibility of controlling and managing certain events that influence his or her decisions. Moreover, we also cannot neglect creativity, especially in the case of competition. Overall, it is considered that there is a certain kind of entrepreneurial personality, involving varying degrees of need for achievement, risk taking propensity, creativity and an internal or external locus of control, which influences the willingness of the individuals to initiate future entrepreneurial activities.

In this study, we intend to analyze the impact of these personality traits on students' entrepreneurial intentions, following the cognitive approaches of the entrepreneurial behavior. However, as this approach has not been completely adequate for our intentions, we have also developed the analysis in a contextual approach, by taking into account a number of external factors that can influence entrepreneurial behavior. There is a belief that entrepreneurial education develops students' ability to approach business situations and to identify new opportunities. Therefore, we tried to select a sample that allows us to make a differentiated analysis, by type of education (entrepreneurial and non-entrepreneurial), and to identify the relevant determinants in expressing the entrepreneurial intentions. In other words, we tried to see how much the entrepreneurial intentions are influenced by certain psycho-behavioral traits of the individual (creativity, locus of control, need for achievement and risk taking propensity), and then, we tried to evaluate the influence of different types of education (entrepreneurial and non-entrepreneurial, bachelor and master) on these intentions, in order to see if entrepreneurial education significantly influences the entrepreneurial intentions of young people. Other variables taken into account were the respondents' gender and age.

\section{The Context of the Analysis}

Romania is among the countries that were part of the communist bloc. During the 50 years of Soviet influence, the social and economic environment has been widely impacted. The centralized economy took the place of the market economy that started to develop in the interwar period, and individual rights and freedoms have been significantly affected. Moreover, the substantial reduction of private property (in Romania, private property became insignificant between 1949 and 1989, less than $10 \%$ of total property, while in Poland, Hungary and other socialist countries, the ratio was over $30 \%$ ) has completed a dismal picture that negatively influenced individuals' behavior. Private businesses have almost completely disappeared, and free initiative was the subject of the persecution of the coercive institutions of the state. Thus, the practices regarding free trade, starting a business, looking for profit or innovation have disappeared, their place being taken by a centralized decision, by excessive planning and the dominance of the social criteria of resources' allocation to the detriment of the economic criteria. The managers of public enterprises had quickly become the single party's representatives and, as a result, they changed the meaning of the management concept. The objective of a public enterprise has changed. It was no longer profit, but the fulfilment of the social or political requirements. Moreover, professional managers completely disappeared; business schools were closed; and the few economic disciplines taught in schools became mere odes dedicated to the party's decisions. Entrepreneurship, as a subject, was taught in Romania only sporadically and to very small groups of students, at the university level.

Therefore, entrepreneurial behaviors and also private businesses were annihilated, thus interrupting the natural cycle of transmitting them in both formal and informal ways. As a result, after the fall of communism, it has been more difficult to rediscover the market economy, entrepreneurship and the role of private property in Romania than in other former socialist countries. At the level of entrepreneurial education, there was a period of about 15 years of hesitating searches, in which a new generation of trainers needed to appear, in which the business schools were reopened and the curriculum was adapted and modernized according to the requirements of the latest developments. Even so, in the absence of a mentality oriented towards economic efficiency, of a respect 
for private property and of a social and family environment favorable to the entrepreneurial activity, private initiative has been very limited and lacked perspective. Only after Romania was forced to achieve some convergence criteria for joining the European Union, some major changes have occurred, initially in the political environment and then in the economic one. The foreign investments attracted after the year 2000 have substantially contributed to the change of the perceptions about businesses, about the role of the entrepreneur and about justifying profit (which until then was analyzed from a Marxist perspective, as a theft committed by the capital owner from the workers' labor). The rupture produced in the mentality was also influenced by the free movement of the labor force, one of the advantages of Romania's adhesion to the European Union. Thus, the workers who migrated to more developed markets have returned with a new perspective on society, with business ideas, with small capital, and they began to realize that well-being is closely related to entrepreneurship.

For a former communist country, such as Romania, the issues concerning entrepreneurship are associated with sustainable growth. A market economy can be developed in a sustainable way by strengthening the private sector, by starting new businesses and by increasing investments and the domestic supply. In their absence, in the long-term, it is very likely for a country to lose much of the growth rate or even to register an economic decline due to the volatility of foreign investments. From the point of view of economic growth, during the 2000's, the downward trend of the 1990s has clearly reversed. The number of newly-established enterprises grew rapidly, but at the same time, the number of bankruptcies or of companies with two or more shareholders that closed dawn increased exponentially, due to the poor entrepreneurial training of the managers, which were often the owners. This trend still exists today. Entrepreneurship is considered to be a process that occurs over time [1,2]. We believe that in the case of Romania, the development of the entrepreneurial spirit, based on a change in perception regarding the role of capital and of the entrepreneur, was and still is a fundamental problem that can make the difference between a success story or a national bankruptcy. In Romania, the growth sustainability can be ensured only through improvements in what the economic theory calls human capital [3] and especially by increasing the level of general education and of entrepreneurial education, in particular. Moreover, social capital, meaning the sum of rules, customs, human relationships and established networks, can positively influence future development [2,4]. The social norms can be changed over time and represent the foundation for other attitudes and traits, which can be improved through formal education.

\section{Literature Review}

The classical approaches assume that the business spirit is the key to individual prosperity. If we recall Adam Smith's famous example with the baker and the butcher, we cannot say that the interaction between the two of them was possible only because each one has identified certain opportunities, but also because each has taken risks to produce a surplus, over his or her own needs, in order to obtain a profit. The classics were less preoccupied by what can be considered psychological stimuli for starting a business, assuming that the individual interest and, eventually, the exogenous innovation capacity were enough. They did not say anything about the individual characteristics, about the influence of the family, the type of education or about other factors that were much later discussed by Ludwig von Mises in Human Action and subsequently in the behavioral approaches of some authors, such as Herbert Simon, Vernon Smith or Robert Shiller.

The entrepreneurial intentions of an individual can be defined as his or her alleged desire to start a business or to form a new organization in the future [5]. These intentions also represent, as Shook, Priem [6] mentioned, a conscious state of mind that precedes the action.

Current analyses regarding entrepreneurial intentions are focused on at least two important directions. The first one was described by Ajzen [7] and was called the Theory of Planned Behaviour (TPB), and the second one was developed by Shapero and Sokol [8] and was named the Model of Entrepreneurial Event (SEE-Shapero's model of Entrepreneurial Event). Ajzen [7] considered that entrepreneurial intentions can be explained by the individual attitudes towards behavior, by the 
subjective norms and the perception of behavioral control. Instead, Shapero and Sokol [8] were focused on the perception of desirability, on the propensity to act and on the perception of feasibility.

Both psycho-sociological analysis models underline a number of traits and perceptions of individuals that lead them to make certain decisions favorable to entrepreneurship. Since none of the models are exhaustive, there were efforts to combine them. One of these attempts belongs to Krueger [9-11], who developed a model of entrepreneurial intentions. He considered that the personal or situational endogenous factors influence the perceived social norms and the perceived desirability, as well as the perceived self-efficacy and perceived feasibility, which, taken together, have a clear influence on entrepreneurial intentions. Combining these approaches is not so difficult, as there are some similarities between what Azjen calls perceived desirability, subjective norm and personal attraction, on the one hand, and the perceived behavioral control from TPB [9], on the other.

The interest in identifying the determinants of entrepreneurial intentions has subsequently generated many studies. Some of them refer to the personal factors of influence (cognitive approach), and others take into account the environmental factors, such as family, school and society (contextual approach). It was found that entrepreneurial intentions do not emerge in every context, as they are the result of the two types of influences mentioned above [12]. However, entrepreneurial intentions, defined as a conscious state of mind that guides attention, experience and behavior towards a planned entrepreneurial action [13], play an important role in the development of the subsequent entrepreneurial activities [14-16]. Bird [17] considered that the entrepreneurial intentions are influenced by both personal and contextual factors. Karimi et al. reached the conclusion that personality traits and contextual factors (i.e., perceived support and perceived barriers) have an impact on attitudes and perceived behavioral control, which in turn influence entrepreneurial intentions [18]. They also found a direct link between perceived barriers and intentions. Other factors that were found to influence attitudes and perceived behavioral control are social capital and human capital (which also showed a direct effect on intentions), as well as the expected benefits of an entrepreneurial activity [2]. Other researchers focused on the direct connection between personality traits and intentions [19], while investigating the potential mediating effect of education [20]. The present study is centered on the relationship between personality traits and the entrepreneurial intentions of the Romanian students. This direct approach was preferred for methodological considerations, specifically due to the need for a balance between the number of concepts that could be evaluated and the precision of the measurement. In order to obtain a more precise evaluation of the individuals' characteristics, validated scales, with a large number of items, were required (Appendix A). Additional concepts would have meant an even larger questionnaire, which in turn could have affected the attitudes of the respondents and, subsequently, the quality of their answers. A potential solution that might be used in a future more complex study is discussed in the Conclusions part of this paper.

Yet, the contextual approaches seem to become more separated from the cognitive ones as entrepreneurial activities require increasingly elaborate knowledge. The most efficient way to acquire such knowledge is through education. Apart from the old opinions, according to which the businessman is generally an individual who does not have time for his or her own education [21], nowadays, the profile of the entrepreneur has changed [22,23]. Moreover, schools have begun to respond to the pressure of the labor market and to introduce in the curricula subjects related to entrepreneurship [24,25], starting from the premise that a graduate does not necessarily have to look for a job, but, instead, he or she can create jobs. Therefore, courses that teach young people to create business plans, to administrate a business or to manage certain situations related to the evolution of the markets are highly sought after in schools and universities [26]. It is true that the obtained results are not always satisfactory, as there are a number of regional cultural factors that have a special influence and require adaptations of the transmitted information [27-29]. There were also negative conclusions, especially by using descriptive and retrospective methods. In these cases, clear connections between entrepreneurship and entrepreneurial education were not identified or were not immediate [30,31]. 


\section{Hypotheses Development}

\subsection{H1: The Need for Achievement Plays an Important Role in Determining Entrepreneurial Intention}

The need for achievement is an important determinant of an individual's entrepreneurial intentions. This assumption belongs to Hansemark [32], who continued a series of analyses conducted by others in this direction [33-38]. As a concept, the need for achievement is the satisfaction felt by an individual when he or she achieves a goal through his or her own efforts. Therefore, it is not surprising that such people are always looking for success, both of their own and of those with whom they are working [39]. However, in order to achieve their goals, they prefer tasks of moderate difficulty, avoiding, as much as possible, the challenges with a high degree of difficulty. At the same time, the tasks that are too easy are not interesting for them [39]. The need for achievement seems to be more important in the case of small and medium businesses [40], being a very good predictor for the entrepreneurial intentions of those who will begin such an activity [41]. Therefore, in our study, we intend to analyze the link between the need for achievement and the entrepreneurial intentions among students, both independently and under the action of exogenous variables.

\subsection{H2: Individuals with a High Degree of Creativity Are More Inclined to Business Activities}

Often, those who were successful in business say that creativity played an important role, especially in identifying opportunities. Porter [42] analyzes the influence of creativity in achieving competitive advantages by continuing the studies conducted by Bird [13] in the same direction. He said that a good balance between intelligence and imagination, which form creativity, can lead to an immediate success [42]. Subsequently, other authors have analyzed the impact of creativity on conducting entrepreneurial activities $[43,44]$. There are even a number of studies focused on the students' entrepreneurial intentions, seen through their self-perceived creativity. We have decided to continue the analysis by introducing some exogenous variables, such as educational background, age, gender, etc., and to determine the relationship between the entrepreneurial intentions, creativity and these variables. In a logical approach, we expect to find that, among young people, the propensity towards entrepreneurship is influenced by creativity, which in its turn is influenced by the field of study pursued in secondary education.

\subsection{H3: Risk Taking Propensity Represents a Common Characteristic of Those Who Intend to Develop Businesses}

The characteristic that sets out a clear difference between an entrepreneur and an employee is the ability to take risks [45-47]. As a business involves many risks, an entrepreneur must have the will to face them and manage them [38,48-50]. The entrepreneurs' capacity of taking risks might be superior even to that of managers, who are known as risk lovers [51,52]. Jackson [53] defined the propensity to take risks as the individual's ability to make certain decisions and actions even under conditions of uncertainty. Where the information is incomplete, the decision-making must be based on the high propensity of the decision-maker towards taking risks. In general, in the specialized literature, this feature is analyzed from various perspectives, being considered a result of what is known as the big five [54]. It is not the only point of view. Some other authors $[55,56]$ consider that the propensity towards risk taking acts as a mediator between the tolerance of ambiguity, the locus of control, the need for achievement and entrepreneurial intentions.

We intended to verify if young people's attitude towards risk has an important role in influencing their entrepreneurial intentions.

\subsection{H4: The External Locus of Control Negatively Influences the Entrepreneurial Intentions of Young People}

The locus of control refers to the individuals' perception regarding their ability to control certain events or actions that influence their lives [57]. According to Zimbardo [58], the locus of control orientation involves assuming the belief that the results of our actions are influenced by what 
we do (this is the internal control orientation) or depend on exogenous factors (external control orientation). It is considered that entrepreneurs, unlike other people, can have a greater control over the results of their actions [59]. The specialized literature explores the link between the locus of control and entrepreneurial intentions, both independently and under the influence of some differentiating variables, such as gender, education, role models, etc. [60-64]. There are also studies that show that the link between the internal locus of control and entrepreneurial intentions is not significant [65]. In the present study, we intend to analyze the relationship between the locus of control type and entrepreneurial intentions, while taking into account other variables, as well.

\subsection{H5: Entrepreneurial Education Significantly Influences the Development of the Personality Traits of Future Entrepreneurs}

Education directly influences the individuals' performance [4]. Moreover, there is a belief that an education focused on entrepreneurship is a catalyst for the development of the entrepreneurial intentions of young people $[9,31,66-72]$. This is the reason why increasingly more schools have introduced in their curriculum subjects related to entrepreneurship [71,73]. Authors like Gasse [74], Johansen and Schanke [75] or Do Paco and Ferreira [76], have studied the way in which entrepreneurial education at the primary or secondary levels influences subsequent choices of young people in business. However, there are also studies that find no clear link between entrepreneurial education and the intentions of young people in developing businesses [30,77,78].

Therefore, we intended to underline that students who are following specializations related to entrepreneurship are more likely to develop the personality traits necessary for developing an entrepreneurial career.

\subsection{H6: Entrepreneurial Intentions Vary Depending on Gender, Age and Level of Education}

The results of the studies that have analyzed the influence of gender on entrepreneurship are not very clear in explaining the differences between men and women with this regard. Generally, men are more involved in business than women, especially in the case of developing countries [79]. However, this situation can also be found in some developed countries, like Belgium [80,81]. If we talk about young people, a study conducted by Chen and Greene [82] shows that young men are more prone to business activities than young women. The same conclusion can be found in BarNir and Watson [83] and Shinnar and Giacomin [81]. As far as education is concerned, it can significantly influence the innovation capability [84], and it can also improve the knowledge and skills necessary for developing a business [85].

We believe that in terms of the entrepreneurial intentions of young people, there are significant differences between men and women, between age groups and between the levels of education, i.e., bachelor's or master's.

\section{Method and Instrument}

A questionnaire-based survey was conducted in order to test the previously-mentioned hypotheses. Respondents included students that were in their final year of undergraduate studies and students enrolled in master degree programs at several Romanian universities, including the Alexandru Ioan Cuza University of Iasi, the Grigore T. Popa University of Medicine and Pharmacy of Iasi, the Bucharest University of Economic Studies or the Babes-Bolyai University of Cluj-Napoca. The respondents were studying various fields, such as economics, arts, medicine, law, computer sciences or agricultural sciences.

The questions were organized into several sections designed to collect data on issues such as educational background, professional status, entrepreneurial intentions and motivations, personality traits and socio-demographic characteristics.

Respondents' entrepreneurial intentions were assessed by asking a question adapted from Wang Lu [86]: "Will you start or manage your own business in the foreseeable future (the next 2 
to 3 years)?" The respondents had to choose from the following options: "I certainly will not", "I'm taking this possibility into consideration", "I certainly will" and "I have already started the procedures to establish my own business". Those who selected the first option were attributed a $0 \%$ probability of becoming entrepreneurs in the next few years. Those who chose the second option received a supplementary opened question that required them to estimate the probability of starting their own business on a scale from $0 \%$ to $100 \%$. Respondents that selected the third or the forth answer were considered to have a $100 \%$ probability. Individuals that said, in a previous question that they already had their own business were also allocated to the $100 \%$ probability.

The four personality traits were evaluated on multi-item scales with possible answers ranging from one (strongly disagree) to five (strongly agree). High scores on these scales indicate that the respondent is more willing to take risks, more creative, has a stronger need for achievement or that he or she tends to assign control to internal factors rather than to external ones.

Innovativeness and the locus of control were evaluated using the items proposed by Mueller and Thomas [87] as adaptations of the Jackson Personality Inventory and the Rotter I-E Scale [57], respectively. The need for achievement was measured using an International Personality Item Pool [88] scale, similar to that found in Tellegen's Multidimensional Personality Questionnaire. Propensity to take risks was also measured using a scale from the International Personality Item Pool [88], which resembled the construct from the Jackson Personality Inventory (JPI-R).

The final form of each of the personality traits items was established after comparing the translated versions of two independent translators and after performing back-translation. In the questionnaire, these items were randomized with the aim of making their purpose less obvious to the respondents and reducing the possible order effect.

After the data were collected, missing responses were filled in using the expectation maximization algorithm [89] in SPSS.

\section{Studied Population and Sample}

The studied population consists of students from the undergraduate (bachelor's) and master's programs within the large state universities of Romania (Alexandru Ioan Cuza University of Iasi, Grigore T. Popa University of Medicine and Pharmacy of Iasi, Bucharest University of Economic Studies or the Babes-Bolyai University of Cluj-Napoca), who have entrepreneurship courses in the content of curricula. (From this population, using the Universities' databases of students, 2200 individuals were randomly selected. These students were contacted by email and asked if they would be willing to take part in a survey. For each University, the message also specified a certain amphitheater, a date and an hour at which the survey would take place. The time was chosen in such a manner that the meeting would not overleap with the students' regular academic activities. At the beginning of the meetings, the participants received more information about the aim of the survey, and they were reminded that their participation was voluntary and their answers would remain anonymous. Afterwards, they received a printed copy of the questionnaire, and they were given a few basic instructions for completing it. In the end, approximately 1000 questionnaires were applied, but the total number of valid questionnaires was 600 . The structure of the analyzed sample, by gender, age groups, employment status and education, can be seen in Table 1).

As far as education is concerned, the profile of the high school that the respondents graduated from was taken into account. In the Romanian upper secondary education, there are a few large areas of study. Each of these may include several profiles, such as sciences, humanities, technical, services, natural resources and environmental protection, military, sports, theology or pedagogy. For the purpose of this survey, only the respondents that graduated in the services profile, which is centered on economic studies, were considered to have an entrepreneurial high school background. 
Table 1. The structure of the analyzed sample.

\begin{tabular}{cccc}
\hline Variable & Categories & Number of Respondents & Percentage (\%) \\
\hline \multirow{2}{*}{ Age } & $18-21$ years & 240 & 40 \\
& $22-24$ years & 293 & 48.8 \\
& 25+ years & 67 & 11.2 \\
\hline \multirow{2}{*}{ Gender } & Female & 356 & 59.3 \\
& Male & 244 & 40.7 \\
\hline \multirow{2}{*}{ Employment status } & Employed & 191 & 31.8 \\
& Not employed & 409 & 68.2 \\
\hline \multirow{2}{*}{ Entrepreneurial high school profile } & Yes & 60 & 10 \\
& No & 540 & 90 \\
\hline \multirow{2}{*}{ Tertiary education level } & Bachelor's & 420 & 70 \\
& Master's & 180 & 30 \\
\hline
\end{tabular}

Another educational factor taken into account was the respondents' level of tertiary education, i.e., bachelor's or master's. The final sample is composed of 420 students in the final year of their bachelor program and 180 students in the first or the second year of a master program. The differentiation was made in order to see if the tertiary education level has a significant impact on the entrepreneurial intentions. This approach was also undertaken by other economists, such as Franco Haase [90] or Kopycinska Bernat [91].

\section{Methods for Data Analysis}

Depending on the research objectives, several data analysis approaches were used in the present study, including Analysis of Variance (ANOVA), Principal Component Analysis (PCA) and General Linear Models (GLM). Data analysis was performed using SPSS 20.0 (IBM Corporation, Armonk, NY, USA).

ANOVA is statistical method for analyzing the variation of a variable depending on one or more categorical variables [92]. In this case, ANOVA was used to test for the presence of significant differences in the probability of starting a business between different categories of the factor variables considered in the analysis, by applying the Least Significance Difference (LSD) test.

The items used in the questionnaire to assess the personality traits were grouped into four large dimensions (creativity, locus of control, achievement and risk), in order to explain the probability of starting a business. PCA is a multivariate descriptive method used for data reduction and for synthesizing them into latent variables [93]. Using PCA, a score was estimated for each dimension, by taking into account the associated items, their positive or negative impact on the total score and the specific influence on the total variation of the estimated score for each dimension. The score for each of the four dimensions was based on the related regression equations:

$$
\begin{gathered}
\text { Score }_{\text {Creativity }}=a_{1} \cdot \mathrm{Q}_{5}+a_{2} \cdot \mathrm{Q}_{11}+a_{3} \cdot \mathrm{Q}_{23}+a_{4} \cdot \mathrm{Q}_{31}+a_{5} \cdot \mathrm{Q}_{3}+a_{6} \cdot \mathrm{Q}_{15}+a_{7} \cdot \mathrm{Q}_{19}+a_{8} \cdot \mathrm{Q}_{33} \\
\text { Score }_{\text {Locus of control }}=b_{1} \cdot \mathrm{Q}_{2}+b_{2} \cdot \mathrm{Q}_{4}+b_{3} \cdot \mathrm{Q}_{16}+b_{4} \cdot \mathrm{Q}_{29}+b_{5} \cdot \mathrm{Q}_{7}+b_{6} \cdot \mathrm{Q}_{14}+b_{7} \cdot \mathrm{Q}_{18}+b_{8} \cdot \mathrm{Q}_{24}+b_{9} \cdot \mathrm{Q}_{26}+b_{10} \cdot \mathrm{Q}_{35} \\
\text { Score }_{\text {Achievement }}=c_{1} \cdot \mathrm{Q}_{6}+c_{2} \cdot \mathrm{Q}_{8}+c_{3} \cdot \mathrm{Q}_{10}+c_{4} \cdot \mathrm{Q}_{12}+c_{5} \cdot \mathrm{Q}_{21}+c_{6} \cdot \mathrm{Q}_{32}+c_{7} \cdot \mathrm{Q}_{1}+c_{8} \cdot \mathrm{Q}_{20}+c_{9} \cdot \mathrm{Q}_{27}+c_{10} \cdot \mathrm{Q}_{36} \\
\text { Score }_{\text {Risk }}=d_{1} \cdot \mathrm{Q}_{13}+d_{2} \cdot \mathrm{Q}_{17}+d_{3} \cdot \mathrm{Q}_{25}+d_{4} \cdot \mathrm{Q}_{30}+d_{5} \cdot \mathrm{Q}_{34}+d_{6} \cdot \mathrm{Q}_{38}+d_{7} \cdot \mathrm{Q}_{9}+d_{8} \cdot \mathrm{Q}_{22}+d_{9} \cdot \mathrm{Q}_{28}+d_{10} \cdot \mathrm{Q}_{37}
\end{gathered}
$$

In these equations, $a_{i=1, \ldots, 8}, b_{j}=1, \ldots, 10, c_{m}=1, \ldots, 10, d_{n}=1, \ldots, 10$ represent the estimations of the parameters from the models related to the four dimensions, and $Q_{e}=1, \ldots, 38$ are the items used in the questionnaire. These items are detailed in Appendix A.

After estimating the scores of the components, their influence on the probability of starting a business (Prob) was assessed. With the help of GLM [94], the analysis also took into account the interactions between the components and the proposed categorical variables, based on the following models:

$$
\text { Prob }=\delta_{0}+\delta_{1} \cdot \text { Creativity }+\delta_{2} \text {. Locus of control }+\delta_{3} \text {.Achievement }+\delta_{4} \cdot \text { Risk }+\varepsilon
$$


Prob $=\delta_{0}+\delta_{1} \cdot$ Creativity $+\delta_{2} \cdot$ Locus of control $+\delta_{3}$. Achievement $+\delta_{4} \cdot$ Risk $+\delta_{5} \cdot$ Control variables $+\varepsilon$

Prob $=\delta_{0}+\delta_{1} \cdot$ Creativity $+\delta_{2} \cdot$ Locus of control $+\delta_{3} \cdot$ Achievement $+\delta_{4} \cdot$ Risk +

$\delta_{5} \cdot$ Control variables $+\delta_{6}$. Creativity. Control variables $+\delta_{7} \cdot$ Locus of control. Control variables +

$\delta_{8} \cdot$ Achievement $\cdot$ Control variables $+\delta_{9} \cdot$ Risk $\cdot$ Control variables $+\varepsilon$

In these cases, $\delta_{i=0, \ldots, 9}$ represent the parameters of the regression models, and Control variables are variables, such as entrepreneurial high school profile, tertiary education level, gender or age.

\section{Results and Discussions}

The main results obtained in this study were focused on:

- $\quad$ Presenting the descriptive statistics and testing the presence of significant differences in the probability of starting a business, according to the categorical variables considered in the analysis;

- Estimating the scores of the four personality dimensions with the help of PCA;

- Estimating the influence of the dimensions (including the interaction between them and the considered control variables) on the probability of starting a business.

These three categories of results are detailed in the following sections of this paper.

\section{Descriptive Statistics and ANOVA Results}

Table 2 presents the mean levels of the probability of starting a business, both for the whole sample and for the various groups formed according to the categorical variables used in the analysis.

Table 2. Descriptive statistics regarding the probability of starting a business in the analyzed sample.

\begin{tabular}{|c|c|c|c|c|c|c|}
\hline Variable & & $n$ & Mean (\%) & Min. (\%) & Max. (\%) & SD \\
\hline \multirow{5}{*}{ High school profile } & Humanities & 175 & 51.43 & 10 & 90 & 11.798 \\
\hline & Sciences & 200 & 50.07 & 15 & 100 & 13.783 \\
\hline & Technical & 83 & 51.51 & 0 & 80 & 16.010 \\
\hline & Services & 60 & 47.06 & 10 & 80 & 15.452 \\
\hline & Others & 2 & 51.48 & 10 & 95 & 16.031 \\
\hline \multirow{2}{*}{ Entrepreneurial high school profile } & Yes & 60 & 47.06 & 10 & 80 & 15.452 \\
\hline & No & 540 & 50.95 & 0 & 100 & 13.897 \\
\hline \multirow{2}{*}{ Tertiary education level } & Bachelor's & 420 & 50.27 & 0 & 100 & 15.452 \\
\hline & Master's & 180 & 51.22 & 10 & 95 & 13.897 \\
\hline \multirow{2}{*}{ Employment status } & Employed & 191 & 51.72 & 10 & 95 & 14.331 \\
\hline & Not employed & 409 & 50.01 & 0 & 100 & 13.968 \\
\hline \multirow{2}{*}{ Gender } & Female & 356 & 50.62 & 0 & 100 & 13.895 \\
\hline & Male & 244 & 50.47 & 0 & 100 & 14.411 \\
\hline \multirow{3}{*}{ Age } & 18 to 21 years & 240 & 49.96 & 0 & 100 & 14.850 \\
\hline & 22 to 24 years & 293 & 50.73 & 10 & 100 & 13.362 \\
\hline & $25+$ years & 67 & 51.94 & 10 & 95 & 14.536 \\
\hline \multicolumn{2}{|l|}{ Total sample } & 600 & 50.56 & 0 & 100 & 14.095 \\
\hline
\end{tabular}

The data in Table 2 illustrate that in terms of statistical means, there are some differences between the various groups related to the variables proposed for the analysis.

Thus, from the point of view of the secondary education's influence on the emergence of the entrepreneurial intentions, humanities and technical high schools have the highest relevance (approximately 51.4\%), followed by those with a sciences profile. Surprisingly, it can be noticed that entrepreneurial education does not necessarily lead to the increase of entrepreneurial intentions. Those who followed a high school in entrepreneurship show their entrepreneurial intention (47.06\%) significantly lower than the graduates of other fields of study, not related to entrepreneurship (50.95\%).

According to the tertiary education level criterion, there are some differences regarding the options for entrepreneurship, with a higher mean for those in the master program (51.72\%) compared 
to those in bachelor studies $(50.27 \%)$. The result is in line with our expectations, considering that each additional year of education positively influences the business orientation of young people.

The results show some differences in the options when the employment criterion is considered. Thus, those who are employed are more tempted to start a business (51.72\%) than those without a job $(50.01 \%)$. The age group is also relevant, as the favorable attitudes towards starting a business increase with age.

Overall, by applying the criteria that give individuals a greater level of confidence in themselves, such as the level of education, employment and age, it can be noticed that people are more and more willing to initiate a business.

The analysis was further enhanced by using ANOVA. Table 3 presents the results of testing the presence of significant differences in the probability of starting a business, by the categories of the categorical variables proposed in the analysis.

Table 3. ANOVA results regarding the presence of significant differences in the probability of starting a business, on different categories.

\begin{tabular}{cccc}
\hline Variable & The Presence of Differences between Categories & F & Sig. \\
\hline High school profile & Only for Services & 1.337 & 0.255 \\
Entrepreneurial high school profile & Yes & 4.133 & 0.042 \\
Tertiary education level & No & 0.576 & 0.448 \\
Employment status & Yes (for an assumed risk of 20\%) & 1.924 & 0.166 \\
Gender & No & 0.016 & 0.899 \\
Age & No & 0.560 & 0.572 \\
\hline
\end{tabular}

Based on the information presented in Table 3, it can be seen that the differences that were previously identified in the probabilities of starting a business are not significant in cases when the respondents are grouped according to their high school profile, gender or age.

Significant differences can be observed when considering the entrepreneurial nature of the field of the high school from which one graduated. The probability of starting a business for the student who graduated from a high school with an entrepreneurship field (i.e., Services) is significantly different from that of the students who graduated from a high school in another field. As the means show, the result is in favor of the graduates from the non-entrepreneurial fields.

With a lower level of trust $(80 \%)$, it can also be seen that there are also differences in the intention of starting a business depending on the status of students: employed or unemployed.

The significant differences estimated for the categorical variables with more than two categories are shown in Table 4.

Table 4. Estimating the significant differences in the probability of starting a business, on different categories.

\begin{tabular}{ccccc}
\hline (I) High School Profile & (J) High School Profile & Mean Difference (I-J) (\%) & Std. Error & Sig. \\
\hline \multirow{2}{*}{ Services } & Humanities & $-4.371^{* *}$ & 2.106 & 0.038 \\
& Sciences & $-3.014^{* * *}$ & 2.072 & 0.146 \\
& Technical & $-4.457^{* *}$ & 2.386 & 0.062 \\
& Others & $-4.420^{* *}$ & 2.392 & 0.065 \\
\hline \multirow{2}{*}{ (I) Age Groups } & (J) Age Groups & Mean Difference (I-J) (\%) & Std. Error & Sig. \\
\hline \multirow{2}{*}{18 to 21 years } & 22 to 24 years & -0.771 & 1.228 & 0.531 \\
& $25+$ years & -1.982 & 1.949 & 0.310 \\
\hline \multirow{2}{*}{22 to 24 years } & 18 to 21 years & 0.771 & 1.228 & 0.531 \\
& $25+$ years & -1.211 & 1.910 & 0.526 \\
\hline \multirow{2}{*}{$25+$ years } & 18 to 21 years & 1.982 & 1.949 & 0.310 \\
& 22 to 24 years & 1.211 & 1.910 & 0.526 \\
\hline
\end{tabular}

\footnotetext{
* The mean difference is significant at the 0.05 level; ${ }^{* *}$ the mean difference is significant at the 0.10 level;

*** the mean difference is significant at the 0.15 level. Test used: LSD.
} 
The data presented in Table 4 confirm the result concerning the entrepreneurial high school profile. It is apparent that in the analyzed sample, there are significant differences between the probabilities of starting a business among students who graduated a high school in Services compared to those from high schools with other profiles. The probability of starting a business in the case of students who graduated a high school in Services is significantly lower than in the case of student with a high school in Humanities (4.371\%), Sciences (3.014\%), Technical (4.457\%) or other high school profiles $(4.420 \%)$.

One possible explanation of this surprising result could be the fact that high schools with the Services profile do not offer their students enough personal development opportunities and do not encourage young people to take responsibilities, be creative and have the desire for achievement. The curricula of these high schools are more focused on the development of professional skills in the field of services and is rather limited in training the young people for specific jobs. It does not provide a broader horizon and does not offer them the opportunity to understand the social and economic phenomena. This is a failed experiment in Romanian education. In fact, there was a substitution of the two-year professional education forms with a longer duration of education, of four years, which leads to the same result: learning a vocational job. This compromise is not beneficial either for the financier (the state) or the beneficiary (the graduate), who extends his or her preparation period with two more years without a visible professional benefit.

In terms of the students' age groups, in the analyzed sample, there are no significant differences in the probability of starting a business, although the means vary slightly. The explanation for this could be the fact that they belong to similar age categories.

According to the results presented in Tables 3 and 4, we can say that there are significant differences between the probability of starting a business based on the Entrepreneurial high school profiles and also on the Employment status. However, the results presented in the same tables also show that entrepreneurial intentions do not vary depending on gender and age, which leads to a partial validation of the hypothesis $\mathrm{H} 6$, which stated that entrepreneurial intentions vary depending on gender, age and level of education.

\section{Estimating the Scores for the Four Dimensions by Using PCA}

By considering the proposed items in the questionnaire and their classification into four main dimensions, a score was estimated for each dimension based on the coefficients of the associated score functions. The estimated coefficients also indicate the importance of the item in explaining the total variance of the probability of starting a business, based on the considered items.

For the creativity dimension, the respondents' answers to the questions $Q_{5}, Q_{11}, Q_{23}$ and $Q_{31}$ positively influence the estimated score of this dimension, while the answers for questions $Q_{3}, Q_{15}$, $\mathrm{Q}_{19}$ and $\mathrm{Q}_{33}$ negatively influence the estimated score.

In the case of the locus of control dimension, the answers of the respondents to the questions $\mathrm{Q}_{2}$, $\mathrm{Q}_{4}, \mathrm{Q}_{16}$ and $\mathrm{Q}_{29}$ negatively influence the estimated score, while the answers for questions $\mathrm{Q}_{7}, \mathrm{Q}_{14}, \mathrm{Q}_{18}$, $\mathrm{Q}_{24}, \mathrm{Q}_{26}$ and $\mathrm{Q}_{35}$ have a positive influence.

For the achievement dimension, positive influence originates from the answers to questions $Q_{6}$, $\mathrm{Q}_{8}, \mathrm{Q}_{10}, \mathrm{Q}_{12}, \mathrm{Q}_{21}$ and $\mathrm{Q}_{32}$, while the answers to questions $\mathrm{Q}_{1}, \mathrm{Q}_{20}, \mathrm{Q}_{27}$ and $\mathrm{Q}_{36}$ have a negative impact.

Finally, for the risk dimension, the answers to the questions $Q_{13}, Q_{17}, Q_{25}, Q_{30}, Q_{34}$ and $Q_{38}$ have a positive influence on the estimated score of this dimension, while the answers to questions $Q_{9}, Q_{22}$, $\mathrm{Q}_{28}$ and $\mathrm{Q}_{37}$ negatively impact the score.

Meanwhile, high levels of the statistical Kaiser-Meyer-Olkin (KMO) test (over 0.7, Table 5) indicate a high level of association between the items (Qi) considered for each dimension. According to Lebart, high levels of this statistic test (KMO) indicate that the items included in the analysis explain in a significant proportion (over 70\%) the variance calculated for each entrepreneurial dimension [95]. Moreover, considering that the items used in PCA significantly influence only one dimension, it can be concluded that the identified dimensions are independent of each other and there are no significant 
correlations between them. This aspect indicates the absence of collinearity among them when testing the influence of the dimensions on the probability of starting a business.

After the coefficients of the score functions associated with each dimension were estimated, several descriptive statistics for the scores were calculated. These are presented in Table 5.

Table 5. Parameter estimates for the score functions of the four entrepreneurial dimensions.

\begin{tabular}{|c|c|c|c|c|c|c|c|}
\hline \multicolumn{2}{|c|}{ Creativity Dimension } & \multicolumn{2}{|c|}{ Locus of Control Dimension } & \multicolumn{2}{|c|}{ Achievement Dimension } & \multicolumn{2}{|c|}{ Risk Dimension } \\
\hline Item & $\begin{array}{l}\text { Parameter } \\
\text { Estimation }\end{array}$ & Item & $\begin{array}{l}\text { Parameter } \\
\text { Estimation }\end{array}$ & Item & $\begin{array}{l}\text { Parameter } \\
\text { Estimation }\end{array}$ & Item & $\begin{array}{l}\text { Parameter } \\
\text { Estimation }\end{array}$ \\
\hline $\mathrm{Q}_{5}$ & 0.303 & $\mathrm{Q}_{2}$ & -0.068 & $\mathrm{Q}_{6}$ & 0.216 & $\mathrm{Q}_{13}$ & 0.257 \\
\hline $\mathrm{Q}_{11}$ & 0.291 & $\mathrm{Q}_{4}$ & -0.027 & $\mathrm{Q}_{8}$ & 0.182 & $\mathrm{Q}_{17}$ & 0.224 \\
\hline $\mathrm{Q}_{23}$ & 0.285 & $\mathrm{Q}_{16}$ & -0.051 & $\mathrm{Q}_{10}$ & 0.234 & $\mathrm{Q}_{25}$ & 0.213 \\
\hline $\mathrm{Q}_{31}$ & 0.206 & $\mathrm{Q}_{29}$ & -0.075 & $\mathrm{Q}_{12}$ & 0.209 & $\mathrm{Q}_{30}$ & 0.272 \\
\hline $\mathrm{Q}_{3}$ & -0.186 & $\mathrm{Q}_{7}$ & 0.249 & $\mathrm{Q}_{21}$ & 0.161 & $\mathrm{Q}_{34}$ & 0.185 \\
\hline $\mathrm{Q}_{15}$ & -0.214 & $\mathrm{Q}_{14}$ & 0.235 & $\mathrm{Q}_{32}$ & 0.210 & $\mathrm{Q}_{38}$ & 0.183 \\
\hline $\mathrm{Q}_{19}$ & -0.151 & $\mathrm{Q}_{18}$ & 0.224 & $\mathrm{Q}_{1}$ & -0.153 & $\mathrm{Q}_{9}$ & -0.120 \\
\hline \multirow[t]{3}{*}{$\mathrm{Q}_{33}$} & -0.059 & $\mathrm{Q}_{24}$ & 0.214 & $\mathrm{Q}_{20}$ & -0.116 & $\mathrm{Q}_{22}$ & -0.112 \\
\hline & & $\mathrm{Q}_{26}$ & 0.264 & $\mathrm{Q}_{27}$ & -0.143 & $\mathrm{Q}_{28}$ & -0.139 \\
\hline & & $\mathrm{Q}_{35}$ & 0.247 & $\mathrm{Q}_{36}$ & -0.192 & $\mathrm{Q}_{37}$ & -0.167 \\
\hline \multicolumn{2}{|c|}{$\mathrm{KMO}=0.731$} & \multicolumn{2}{|c|}{$\mathrm{KMO}=0.772$} & \multicolumn{2}{|c|}{$\mathrm{KMO}=0.750$} & \multicolumn{2}{|c|}{$\mathrm{KMO}=0.736$} \\
\hline \multicolumn{2}{|c|}{ Sig. $=0.000$} & \multicolumn{2}{|c|}{ Sig. $=0.000$} & \multicolumn{2}{|c|}{ Sig. $=0.000$} & \multicolumn{2}{|c|}{ Sig. $=0.000$} \\
\hline
\end{tabular}

KMO (Kaiser-Meyer-Olkin Measure of Sampling Adequacy). Extraction method: Principal Component Analysis (PCA). Rotation method: Varimax with Kaiser normalization. Component scores.

The scores follow a normal distribution with a mean of zero and a variance of one (see Table 6). For the creativity dimension, positive values of the score indicate that the creativity variable plays an important role in expressing their entrepreneurial intentions, and negative values indicate that individuals without creativity have less inclination to entrepreneurship. In the case of the locus of control dimension, positive values of the score indicate that those who assign control to external factors have a lower propensity towards entrepreneurship, and negative values indicate an internal localization of control and a positive impact on entrepreneurial intentions. In the achievement dimension, positive values of the score indicate that the need for achievement has an important role in expressing the entrepreneurial intentions, while the negative values show that, in the absence of this need, the entrepreneurial intentions diminish. As far as the risk dimension is concerned, positive values of the score reflect the fact that a higher ability of taking risks leads to encouraging the entrepreneurial intentions; negative values indicate a negative impact of the lack of ability of taking risks on the desire of developing businesses.

Table 6. Descriptive statistics regarding the scores estimated for the four dimensions.

\begin{tabular}{cccccc}
\hline Dimension & $\boldsymbol{n}$ & Mean & Min. & Max. & Std. Deviation \\
\hline Creativity & 600 & 0.000 & -3.429 & 2.417 & 1.000 \\
Locus of control & 600 & 0.000 & -2.329 & 2.447 & 1.000 \\
Achievement & 600 & 0.000 & -2.874 & 2.254 & 1.000 \\
Risk & 600 & 0.000 & -2.685 & 3.168 & 1.000 \\
Valid $n$ (listwise) & 600 & & & & \\
\hline
\end{tabular}

\section{Estimating the Influence of the Components on the Probability of Starting a Business}

In this stage of the research, we developed six regression models through which we tried to determine the influence of the main variables that were analyzed (creativity, locus of control, achievement, risk) and of some control variables (entrepreneurial high school profile, tertiary education level, gender and age) on the entrepreneurial intentions. We have to mention that, based on the results of the PCA, the entrepreneurial dimensions of the students are independent of each other, which indicates the absence of significant correlations between them.

These models are discussed in more detail in the following paragraphs. 
According to Model 1, it can be assumed, with a 95\% level of confidence, that the average probability of an individual from the sample to start a business is $50.556 \%$, regardless of the factors' influence. From the point of view of the four personality dimensions, in Table 7, it can be noticed that the creativity and locus of control dimensions do not have a significant influence on the probability of starting a business. However, this probability is significantly influenced by the achievement and risk dimensions. An increase by one unit in the achievement dimension leads to a $0.961 \%$ increase in the probability of starting a business, while an increase of a unit in the risk dimension generates a more significant increase, of $1.538 \%$. Based on this result, we can say that the hypothesis H1 (the need for achievement plays an important role in determining the entrepreneurial intention) and $\mathrm{H} 3$ (the risk taking propensity represents a common characteristic of those who intend to develop businesses) are validated.

Table 7. The estimates of the regression model's parameters regarding the influence of the dimensions on the probability of starting a business.

\begin{tabular}{|c|c|c|c|c|c|c|}
\hline Factor & Model 1 & Model 2 & Model 3 & Model 4 & Model 5 & Model 6 \\
\hline Intercept & 50.556 & 51.769 & 50.905 & 50.912 & 51.146 & 51.092 \\
\hline Creativity & 0.692 & 0.737 & 0.651 & 0.253 & 0.723 & -0.094 \\
\hline Sig. & $(0.307)$ & $(0.281)$ & $(0.336)$ & $(0.720)$ & $(0.287)$ & $(0.943)$ \\
\hline Locus of control & 0.327 & 0.284 & 0.328 & 0.291 & 0.315 & -0.269 \\
\hline Sig. & $(0.582)$ & $(0.633)$ & $(0.579)$ & $(0.642)$ & $(0.596)$ & $(0.809)$ \\
\hline Achievement & $0.961^{* * *}$ & $0.891^{* * * *}$ & $0.953^{* * *}$ & 0.636 & $0.917^{* * *}$ & 1.166 \\
\hline Sig. & $(0.129)$ & $(0.162)$ & $(0.132)$ & $(0.343)$ & $(0.149)$ & $(0.345)$ \\
\hline Risk & $1.538^{*}$ & $1.608^{*}$ & $1.512 *$ & 1.763 * & $1.532 *$ & -0.144 \\
\hline Sig. & $(0.016)$ & $(0.013)$ & $(0.017)$ & $(0.008)$ & $(0.016)$ & $(0.908)$ \\
\hline $\begin{array}{l}\text { Entrepreneurial high school profile } \\
\text { Sig. }\end{array}$ & - & $\begin{array}{l}-3.394^{* *} \\
(0.076)\end{array}$ & $\begin{array}{l}-3.493^{* *} \\
(0.066)\end{array}$ & $\begin{array}{l}-2.897^{* * *} \\
(0.130)\end{array}$ & - & - \\
\hline $\begin{array}{l}\text { Tertiary education level } \\
\text { Sig. }\end{array}$ & - & $\begin{array}{l}-0.347 \\
(0.811)\end{array}$ & - & - & $\begin{array}{l}-0.843 \\
(0.501)\end{array}$ & $\begin{array}{c}1.074 \\
(0.482)\end{array}$ \\
\hline $\begin{array}{l}\text { Gender } \\
\text { Sig. }\end{array}$ & - & $\begin{array}{l}1.203 \\
(0.322)\end{array}$ & - & - & - & - \\
\hline $\begin{array}{l}\text { Age (19 to } 21) \\
\text { Sig. }\end{array}$ & - & $\begin{array}{l}-1.773 \\
(0.408)\end{array}$ & - & - & - & - \\
\hline $\begin{array}{l}\text { Age (22 to } 24) \\
\text { Sig. }\end{array}$ & - & $\begin{array}{l}-1.300 \\
(0.502)\end{array}$ & - & - & - & - \\
\hline $\begin{array}{c}\text { High school: Creativity } \\
\text { Sig. }\end{array}$ & - & - & - & $\begin{array}{l}4.128 * * \\
(0.089)\end{array}$ & - & $\begin{array}{c}1.074 \\
(0.482)\end{array}$ \\
\hline $\begin{array}{c}\text { High school: Locus of control } \\
\text { Sig. }\end{array}$ & - & - & - & $\begin{array}{l}-1.441 \\
(0.479)\end{array}$ & - & $\begin{array}{c}0.841 \\
(0.523)\end{array}$ \\
\hline $\begin{array}{c}\text { High school: Achievement } \\
\text { Sig. }\end{array}$ & - & - & - & $\begin{array}{l}2.958^{* * * *} \\
(0.168)\end{array}$ & - & $\begin{array}{l}-0.369 \\
(0.798)\end{array}$ \\
\hline $\begin{array}{l}\text { High school: Risk } \\
\text { Sig. }\end{array}$ & - & - & - & $\begin{array}{l}-1.804 \\
(0.390)\end{array}$ & - & $\begin{array}{c}2.243^{* * *} \\
(0.122)\end{array}$ \\
\hline $\mathrm{R}^{2}$ & 0.028 & 0.036 & 0.033 & 0.048 & 0.028 & 0.037 \\
\hline Observations & 600 & 600 & 600 & 600 & 600 & 600 \\
\hline
\end{tabular}

Dependent variable: probability of starting a business. * The estimation is significant at the 0.05 level; ** the estimation is significant at the 0.10 level; ${ }^{* * *}$ the estimation is significant at the 0.15 level; ${ }^{* * * *}$ the estimation is significant at the 0.20 level.

The fact that the creativity trait does not play a significant role may suggest that the perception of the business environment is not a correct one. If we add the fact that the locus of control does not significantly influence the entrepreneurial intentions, we can deduce that the area of entrepreneurship in Romania is perceived by young people as one characterized by risk, where only those who dare and who are lucky can succeed. This perception is somewhat worrying because the accent is put on luck and not on a serious analysis of the market context, on the identification of long-term opportunities and on the systematic development of a business. This result allows us to reject the hypothesis $\mathrm{H} 4$ (external locus of control negatively influences the entrepreneurial intentions of the young people).

In Model 2, unlike in the previous one, the influences of some categorical factors (control variables) are added to the analysis. Among these we can see that the variable entrepreneurial high school profile has a significant influence on the probability of starting a business, i.e., a student who previously graduated an entrepreneurship high school will have a 3.493\% lower probability of starting a business 
(meaning $48.375 \%=51.769 \%-3.394 \%$ ). Based on these results, we can say that hypothesis H5 (entrepreneurial education significantly influences the development of the personality traits of the future entrepreneurs) is validated, when introducing the control variables in the analysis. The other control variables (tertiary education level program, gender, age), if they act individually, they do not have a significant influence on the probability of starting a business. This result strengthens the idea noticed in previous analyses. The high schools considered by us as entrepreneurial, able to develop specific skills for the business environment, fail to achieve their goals. There may be two explanations. One is related to the quality of the students enrolled in these high schools. These institutions are generally considered marginal, and therefore, they are in the last positions on the options' list in the selection process. This problem can be solved by implementing measures to ensure greater efficiency, by attracting better teachers, by offering other benefits, by changing the curricula, etc. The second explanation may be related to a much deeper problem, a structural one: orienting young people towards business is not done in specialized institutions or by offering specialized courses (see $[30,77,78]$ ), but by a good general training. As proof of this, our analyses revealed that the largest entrepreneurial intentions can be found among students who have finished high schools in sciences and humanities.

Model 3 includes in the analysis the influence of the personality dimensions and that of the field of the high school. Other variables, such as gender, age or tertiary education level, were excluded because Model 2 showed that they have no significant influence. The final result presents slight modifications and reinforces the opinion according to which the graduates who finished the field of study Entrepreneurship are less inclined to business than the rest. In this case, the hypothesis $\mathrm{H} 5$ is also validated.

Unlike previous models, Model 4 includes in the analysis the interactions between factors. The influence of the personality dimensions on the entrepreneurial intentions is examined while taking into account the graduated high school field (entrepreneurial or not). The reference category is the "high school field other than entrepreneurship". The results show that, depending on the field of the graduated high school, only the risk dimension has a significant influence on the probability of starting a business. An increase of one unit of the value of this dimension leads to an increase of $1.763 \%$ of the probability of starting a business. Moreover, a student who previously graduated a high school in entrepreneurship will have a probability of starting a business with $2.897 \%$ lower than the one who did not graduate such a high school.

However, the field of the high school from which one graduated significantly influences some of the four personality dimensions. Increasing the creativity dimension of the students who graduated a high school with the entrepreneurial profile determines an increase of $4.128 \%$ of the probability of starting a business, unlike those who have completed high schools with other profiles, where increasing the creativity dimension had a non-significant influence. This result allows us to validate the hypothesis $\mathrm{H} 2$ (the individuals with a high degree of creativity are more inclined to business activities) in the case of the students who graduated a high school with an entrepreneurial profile. Increasing the achievement dimension would lead to an increase of $2.958 \%$ of the entrepreneurial intentions of the graduates. These results come to strengthen our opinion from Model 2, according to which the curriculum of high schools in entrepreneurship should be substantially changed, in order to encourage some general traits, such as creativity.

The field of the high school from which one graduated does not have a significant influence on the locus of control dimension. Increasing the risk dimension in the case of students who graduated a high school with an entrepreneurial profile determines a decrease of $2.958 \%$ of the probability of starting a business, unlike those who graduated a high school with other profiles, where the risk dimension had a positive influence of $1.763 \%$. The fact that they have finished high schools with an entrepreneurial profile indicates that they become good at executing tasks, but less inclined to start their own business. The analysis of the risk dimension also strengthens our previous findings. The more specialized in 
entrepreneurship is the secondary education, the more the intentions are influenced by risk taking propensity and not by intelligence or creativity.

In Model 5, the analysis includes the four dimensions and, independently, the influence of the tertiary education level (bachelor's or master's). The reference category is the "master's level". Depending on the program level, the achievement and risk dimensions have a significant influence on the probability of starting a business (the hypotheses $\mathrm{H} 1$ and $\mathrm{H} 3$ are validated in this case, as well). An increase of one unit in the value of the achievement dimension leads to an increase of $0.917 \%$ of the probability of starting a business, under the influence of the studied program, and an increase of one unit of the risk dimension leads to an increase of $1.532 \%$ of the probability of starting a business, under the influence of the studied program. However, at the level of the analyzed sample, there are no significant differences in the probability of starting a business among the different types of programs.

In the case of Model 6, the interactions between factors are included in the analysis, in a similar manner to that used in Model 4, i.e., the influence of the dimensions in relation with the tertiary education level (bachelor's or master's) is taken into account. The reference category here is the "master's level". In the case of the master's students, the four dimensions have no significant influence. For the bachelor's students, increasing the value of the risk dimension with one unit generates an increase of $2.243 \%$ of the probability of starting a business (which leads to the validation of the hypothesis H3 in the case of the bachelor's students). This fact shows that when the level of tertiary education increases, the risk no longer plays such an important role in expressing the entrepreneurial intentions. However, it is not clear if the need for achievement is stronger.

\section{Conclusions}

The analyses conducted in our study have generated some interesting results, through which the proposed research hypotheses were more or less validated: $\mathrm{H1}, \mathrm{H} 2, \mathrm{H} 3, \mathrm{H} 5$ and $\mathrm{H} 6$ were validated, while $\mathrm{H} 4$ was rejected. Based on the obtained results, we can say that the hypothesis concerning the dependence between the need for achievement and entrepreneurship is validated. As in the case of the American and Irish students from Pillis and Reardon's study [41], the Romanian students want to develop businesses in order to achieve a higher state of well-being, considering this as a personal fulfilment. It seems that young students show a significant need to gain recognition, and starting a business can be a good way to obtain this. The result illustrates to some extent that the new generations are increasingly aware of the fact that the free market is the one that leads to prosperity, and entrepreneurship is a good way to self-realization.

However, the results do not clearly show whether creativity also plays a role in the development of entrepreneurial intentions. Unlike the results obtained by Zampetakis and Moustakis [43], the level of confidence for the analysis is not relevant, although the items chosen for testing were selected by taking into consideration established papers related to TPB. Creativity is linked to the innovation ability and enhancing the imagination. Both the family and the school play an important role towards this regard. Yet, in this respect, the educational system in Romania is known to be lacking; it is still focused on acquiring formal knowledge on and not on skills' development. Therefore, we believe that the nonsignificant results were because of the contradiction between the received education and free spirit, typical for the young age of the respondents. It is an accepted fact that if a student gets in touch with a creative environment, with teachers who encourage this, the individual creativity will increase [96]. Therefore, it is expected that the reform of the Romanian education system should take into account this aspect. Nowadays, this system is oriented towards the accumulation of formal knowledge and towards accumulation through learning and not through experimentation and discovery. It is expected that a change of the center of gravity from a classic teaching-learning system towards self-learning and critical analysis would bring substantial improvements in the role of creativity.

The third hypothesis was focused on the propensity towards taking risks as a characteristic of those who intend to develop a business in the future. In the study, we assumed that young people with a higher capacity for taking risks are more attracted to the entrepreneurial environment, considering 
that starting and managing a business often requires good risk management. Our assumption has been validated, as the obtained results have a high degree of confidence.

Regarding the locus of control, the results were not conclusive. It is not clear whether there is any connection between young people's entrepreneurial intentions and their perception of the control over some events and actions of their lives. Although we were tempted to believe that the external locus of control could restrain the desire to start a business, we cannot say with certainty that this is true for Romanian students.

We assumed the hypothesis that entrepreneurial education in high school could increase the students' desire to engage in entrepreneurial activities. The analysis revealed that, on the contrary, the formal entrepreneurial education received from schools specialized in this field has an inhibiting effect on the main determinants of the entrepreneurial intentions. The graduates of the high schools with an entrepreneurial field are less inclined to engage in businesses compared to the graduates of the high schools that offer sciences, humanities or other types of general education. A possible explanation could be given by the lower quality of the human factor, knowing that, during the admission process for the ninth grade, the best candidates prefer high schools of a general profiles, where the quality of education is considered to be much better. Another explanation could be related to the structure of curricula in the entrepreneurial high schools, which is more focused on specific jobs and is not sufficiently oriented towards stimulating knowledge and adaptation abilities and enhancing entrepreneurial skills. In fact, the entrepreneurial high schools are more focused on developing professional skills typical for certain jobs, such as accountants, salespersons, travel agents, etc.

The results of the study were also analyzed by using several socio-demographic criteria. There were no significant differences between women and men, as the responses of both genders presented a certain uniformity. Because the sample was extracted from a population of students, the possibility of classifying it by the age criteria was quite low, so the differences obtained were not relevant. Thus, the hypothesis that entrepreneurial intentions differed by gender and age could not be confirmed. From the point of view of the tertiary education level, the results were also inconclusive. We cannot say with certainty whether the master's students have a higher propensity towards entrepreneurial activities than those from the bachelor's program. However, developing the analysis in terms of the interaction between factors (i.e., the influence of the personality dimensions on different cycles of study), we found out that students from the bachelor's program have a higher risk component in assessing their entrepreneurial intentions. This is normal if we consider the fact that most of the studies have shown that increasing the educational level diminishes the risk taking propensity.

However, it should be noted that in the case of Romania, as well as in other countries, the increase of entrepreneurial activities is a major issue [97] on which the sustainability of future growth depends. Any market economy is based on an extensive and dynamic private sector. However, the state can help by targeting its educational policies towards encouraging and supporting entrepreneurial education. As a number of studies argue [1], it is necessary to introduce specialized courses in all of the universities and also to create some alternatives to these university studies, like the Graduate Enterprise Programme in the U.K. or the Norway Entrepreneur-Service [98].

Our research has certain limits related to the structure of the sample and to its representativeness. As seen in the descriptive analysis, the number of graduates from an entrepreneurial field in secondary education is low. We intend, in future research, to control the sample in this respect. Moreover, we have chosen only a few determinants of the entrepreneurial intentions, such as the propensity to take risks, the need for achievement, the locus of control and the creativity, neglecting many other potential factors. We intend, in a future study, to also identify the importance of other determinants. Other studies took into account the effect of some contextual factors, such as the support and barriers that the respondent perceives in relation to entrepreneurship [18], as well as the influence of the expected benefits and the human and social capital on entrepreneurial intentions [2]. Moreover, unlike these studies, our research was focused on the direct effect of the factors on the respondents' intentions, without considering the potential impact on the TBP components, which in turn affect the intentions. However, measuring more 
concepts and variables would have resulted in a significantly larger questionnaire, with a potential negative effect on the precision of the evaluation. In the future, we intend to spread the items associated with these concepts over several questionnaires that could be sent to the same respondents within a reasonable timeframe. There are some specialized online survey platforms that allow the assignment of the responses from several questionnaires to specific respondents. Another research limit results from the fact that the study did not take into consideration the interaction between the main entrepreneurial identified dimensions. Therefore, in future research, we intend to use the structural equation models to study the influence of the entrepreneurial dimensions on the probability of starting a business, taking into account the interdependencies between the four identified dimensions.

Therefore, from a methodological point of view, our study differs from others $[2,18,99,100]$, as it identifies several discrete dimensions of the students' entrepreneurial intentions. In the aforementioned studies, structural equation modelling was used in order to test the direct and indirect influences of various factors that could affect one or several of the dimensions proposed in the specialized literature. In our study, we made use of principal component analysis with the intention of identifying the elements that impact a single dimension. Although this might represent a limit of our research, it also allowed for a refinement of the investigation of the determinants of the students' intentions, as a score was estimated for each dimension and was used to analyze the influence of newly-identified dimensions on the entrepreneurial decisions.

Author Contributions: All authors contributed equally to this paper. Cristian C. Popescu described the context of the analysis and conducted, together with Laura Diaconu (Maxim), Andrei Maxim and Ionel Bostan, the literature review and the hypothesis development. Andrei Maxim, with the help of the other authors, developed the research approach and designed the questionnaire. All authors were involved in the data collection process. Ioan-Bogdan Robu, supported by the other authors, performed the data analysis and described the main results. Cristian C. Popescu and Ionel Bostan formulated the main conclusions. Andrei Maxim and Ioan-Bogdan Robu presented the limitations and the possible future developments of this research. Laura Diaconu (Maxim) and Ionel Bostan edited the paper.

Conflicts of Interest: The authors declare no conflict of interest.

\section{Appendix A}

Items of the personality traits scales.

\begin{tabular}{cl}
\hline $\mathbf{Q}$ & Item \\
\hline 1 & I have a slow pace to my life \\
2 & Whether or not I am successful in life depends mostly on my ability \\
3 & I like a job which demands skill and practice rather than inventiveness \\
4 & I feel in control of my life \\
5 & I prefer work that requires original thinking \\
6 & I excel in what I do \\
7 & My success depends on whether I am lucky enough to be in the right place at the right time \\
8 & I work too much \\
9 & I would never go hang-gliding or bungee-jumping \\
10 & I continue until everything is perfect \\
11 & People often ask me for help in creative activities \\
12 & I work hard \\
13 & I seek danger \\
14 & Success in business is mostly a matter of luck \\
15 & I am not a very creative person \\
16 & When I get what I want, it is usually because I worked hard for it \\
17 & I take risks \\
18 & I feel that what happens in my life is mostly determined by people in powerful positions \\
19 & I obtain more satisfaction from mastering a skill than coming up with a new idea \\
20 & I am not highly motivated to succeed
\end{tabular}




\begin{tabular}{ll}
\hline Q & Item \\
\hline 21 & I do more than what's expected of me \\
22 & I would never make a high risk investment \\
23 & I often surprise people with my novel ideas \\
24 & It is not wise for me to plan too far ahead, because things turn out to be a matter of bad fortune \\
25 & I am willing to try anything once \\
26 & To a great extent my life is controlled by accidental happenings \\
27 & I do just enough work to get by \\
28 & I stick to the rules \\
29 & My life is determined by my own actions \\
30 & I seek adventure \\
31 & I like to experiment with various ways of doing the same thing \\
32 & I plunge into tasks with all my heart \\
33 & I usually continue doing a new job in exactly the way it was taught to me \\
34 & I enjoy being reckless \\
35 & When I get what I want, it is usually because I am lucky \\
36 & I do too little work \\
37 & I avoid dangerous situations \\
38 & I know how to get around the rules
\end{tabular}

\section{References}

1. Liñán, F.; Rodríguez-Cohard, J.C. Assessing the stability of graduates' entrepreneurial intention and exploring its predictive capacity. Acad. Rev. Latinoam. Adm. 2015, 28, 77-98. [CrossRef]

2. Goethner, M.; Obschonka, M.; Silbereisen, R.K.; Cantner, U. Scientists' transition to academic entrepreneurship: Economic and psychological determinants. J. Econ. Psychol. 2012, 33, 628-641. [CrossRef]

3. Popescu, C. Human Capital in New Democracies (Capitalul Uman in Noile Democratii); Al. I. Cuza University Press: Iasi, Romania, 2015.

4. Popescu, C., Pohoață, I., Eds.; Capital Uman, Capital Social și Creștere Economică (Human Capital, Social Capital and Economic Growth); Al. I. Cuza University Press: Iasi, Romania, 2007.

5. Gartner, W.B. "Who is an Entrepreneur?" Is the Wrong Question. Am. J. Small Bus. 1988, 12, 11-32.

6. Shook, C.L.; Priem, R.L.; McGee, J.E. Venture Creation and the Enterprising Individual: A Review and Synthesis. J. Manag. 2003, 29, 379-399.

7. Ajzen, I. Theory of planned behaviour. Organ. Behav. Hum. Dec. Process. 1991, 50, 179-211. [CrossRef]

8. Shapero, A.; Sokol, L. The social dimension of entrepreneurship. In The Encyclopedia of Entrepreneurship; Kent, C.A., Sexton, D.L., Vesper, K.H., Eds.; Prentice-Hall: Englewood Cliffs, NJ, USA, 1982.

9. Krueger, N.F.; Brazeal, D.V. Entrepreneurial potential and potential entrepreneurs. Entrep. Theory Pract. 1994, 18, 91-104.

10. Krueger, N.F.; Carsrud, A.L. Entrepreneurial intentions: Applying the theory of planned behaviour. Entrep. Reg. Dev. 1993, 5, 315-330. [CrossRef]

11. Krueger, N.F.; Reilly, M.D.; Carsrud, A.L. Competing models of entrepreneurial intentions. J. Bus. Ventur. 2000, 15, 411-432. [CrossRef]

12. Krueger, N.F. What Lies Beneath? The Experiential Essence of Entrepreneurial Thinking. Entrep. Theory Pract. 2007, 31, 123-138. [CrossRef]

13. Bird, B. Entrepreneurial Behavior; Scott Foresman: Glenview, IL, USA, 1989.

14. Abbey, A. Cross-Cultural Comparison of the Motivation for Entrepreneurship. J. Bus. Entrep. 2002, 14, 69-82.

15. Kautonen, T.; van Gelderen, M.; Fink, M. Robustness of the Theory of Planned Behavior in Predicting Entrepreneurial Intentions and Actions. Entrep. Theory Pract. 2015, 39, 655-674. [CrossRef]

16. Kibler, E.; Kautonen, T.; Fink, M. Regional Social Legitimacy of Entrepreneurship: Implications for Entrepreneurial Intention and Start-up Behaviour. Reg. Stud. 2014, 48, 995-1015. [CrossRef]

17. Bird, B. Implementing Entrepreneurial Ideas: The Case for Intention. Acad. Manag. Rev. 1988, 13, 442-453. 
18. Karimi, S.; Biemans, H.J.; Naderi Mahdei, K.; Lans, T.; Chizari, M.; Mulder, M. Testing the relationship between personality characteristics, contextual factors and entrepreneurial intentions in a developing country. Int. J. Psychol. 2015. [CrossRef] [PubMed]

19. Uddin, M.D.R.; Bose, T.K. Determinants of Entrepreneurial Intention of Business Students in Bangladesh. Int. J. Bus. Manag. 2012, 7, 128-137. [CrossRef]

20. Ertuna, Z.I.; Gurel, E. The moderating role of higher education on entrepreneurship. Educ. Train. 2011, 53, 387-402.

21. Jacobowitz, A.; Vilder, D. Characteristics of entrepreneurs: Implications for vocational guidance. Vocat. Guid. Q. 1982, 30, 252-257. [CrossRef]

22. Bates, T. Self-employment entry across industry groups. J. Bus. Ventur. 1995, 10, 143-156. [CrossRef]

23. Jayawarna, D.; Rouse, J.; Kitching, J. Entrepreneur motivations and life course. Int. Small Bus. J. 2013, 31, 34-56. [CrossRef]

24. O'Connor, A. A conceptual framework for entrepreneurship education policy: Meeting government and economic purposes. J. Bus. Ventur. 2013, 28, 546-563. [CrossRef]

25. Zhao, Y. World Class Learners: Educating Creative and Entrepreneurial Students; Corwin Press: Thousand Oaks, CA, USA, 2012.

26. Gibb, A. In pursuit of a new 'enterprise' and 'entrepreneurship' paradigm for learning: creative destruction, new values, new ways of doing things and new combinations of knowledge. Int. J. Manag. Rev. 2002, 4, 233-269. [CrossRef]

27. Obschonka, M.; Stuetzer, M.; Gosling, S.D.; Rentfrow, P.J.; Lamb, M.E.; Potter, J.; Audretsch, D.B. Entrepreneurial Regions: Do Macro-Psychological Cultural Characteristics of Regions Help Solve the "Knowledge Paradox" of Economics? PLoS ONE 2015, 10, e0129332. [CrossRef] [PubMed]

28. Thornton, P.H.; Ribeiro-Soriano, D.; Urbano, D. Socio-cultural factors and entrepreneurial activity: An overview. Int. Small Bus. J. 2011, 29, 105-118. [CrossRef]

29. Popescu, C.; Maxim, A.; Diaconu, L. Determinants of Entrepreneurial Intentions among Romanian Students. Transform. Bus. Econ. 2014, 13, 370-388.

30. Alberti, F. Entrepreneurship education: Scope and theory. In Entrepreneurial Knowledge and Learning: Conceptual Advances and Directions for Future Research; Salvato, C., Davidsson, P., Persson, A., Eds.; Jonkoping International Business School: Jonkoping, Sweden, 1999.

31. Raposo, M.; Do Paço, A. Entrepreneurship education: Relationship between education and entrepreneurial activity. Psicothema 2011, 23, 453-457. [PubMed]

32. Hansemark, O.C. Need for achievement, locus of control and the prediction of business start-ups: A longitudinal study. J. Econ. Psychol. 2003, 24, 301-319. [CrossRef]

33. Johnson, B.R. Toward a multidimensional model of entrepreneurship: The case of achievement motivation and the entrepreneur. Entrep. Theory Pract. 1990, 14, 39-54.

34. Lynn, R. An achievement motivation questionnaire. Br. J. Psychol. 1969, 60, 529-534. [CrossRef]

35. McClelland, D.C. The Achieving Society; Van Nostrand: Princeton, NJ, USA, 1961.

36. McClelland, D.C. Managing motivation to expand human freedom. Am. Psychol. 1978, 33, $201-210$. [CrossRef]

37. McClelland, D.C. Characteristics of Successful Entrepreneurs. J. Creat. Behav. 1987, 21, 219-233. [CrossRef]

38. Brandstätter, H. Personality aspects of entrepreneurship: A look at five meta-analyses. Personal. Individ. Differ. 2011, 51, 222-230. [CrossRef]

39. Rauch, A.; Frese, M. Psychological approaches to entrepreneurial success. A general model and an overview of findings. In International Review of Industrial and Organizational Psychology; Cooper, C.L., Robertson, I.T., Eds.; Wiley: Chichester, UK, 2000; Volume 15, pp. 101-142.

40. Hattie, J. Visible Learning: A Synthesis of over 800 Meta-Analyses Relating to Achievement; Routledge: Abingdon-on-Thames, UK, 2013.

41. Pillis, E.; Reardon, K.K. The influence of personality traits and persuasive messages on entrepreneurial intention: A cross-cultural comparison. Career Dev. Int. 2007, 12, 382-396.

42. Porter, M.E. On Competition; Harvard Business School Press: Boston, MA, USA, 1998.

43. Zampetakis, L.A.; Moustakis, V. Linking creativity with entrepreneurial intention: A structural approach. Int. Entrep. Manag. J. 2006, 2, 413-428. [CrossRef] 
44. Baron, R.A.; Tang, J. The role of entrepreneurs in firm-level innovation: Joint effects of positive affect, creativity, and environmental dynamism. J. Bus. Ventur. 2011, 26, 49-60. [CrossRef]

45. Hvide, H.K.; Panos, G.A. Risk tolerance and entrepreneurship. J. Financ. Econ. 2014, 111, 200-223. [CrossRef]

46. Kreiser, P.; Marino, L.; Kuratko, D.; Weaver, K.M. Disaggregating entrepreneurial orientation: The non-linear impact of innovativeness, proactiveness and risk-taking on SME performance. Small Bus. Econ. 2013, 40, 273-291. [CrossRef]

47. Drucker, P. Innovation and Entrepreneurship; Routledge: New York, NY, USA, 2014.

48. Hisrich, R.D.; Peters, M.P. Entrepreneurship, 5th ed.; McGraw-Hill Irwin: Boston, MA, USA, 2002.

49. Rauch, A.; Frese, M. Let's put the person back into entrepreneurship research: A meta-analysis on the relationship between business owners' personality traits, business creation, and success. Eur. J. Work Organ. Psychol. 2007, 16, 353-385. [CrossRef]

50. Zhao, H.; Seibert, S.E.; Lumpkin, G.T. The Relationship of Personality to Entrepreneurial Intentions and Performance: A Meta-Analytic Review. J. Manag. 2010, 36, 381-404. [CrossRef]

51. Stewart, W.H., Jr.; Roth, P.L. Risk propensity differences between entrepreneurs and managers: A meta-analytic review. J. Appl. Psychol. 2001, 86, 145-153. [CrossRef] [PubMed]

52. Stewart, W.H., Jr.; Roth, P.L. A Meta-Analysis of Achievement Motivation Differences between Entrepreneurs and Managers*. J. Small Bus. Manag. 2007, 45, 401-421. [CrossRef]

53. Jackson, D.N. Jackson Personality Inventory: Revised Manual; Sigma Assessment Systems, Inc.: Port Huron, MI, USA, 1994.

54. Nicholson, N.; Soane, E.; Fenton-O'Creevy, M.; Willman, P. Personality and domain-specific risk taking. J. Risk Res. 2005, 8, 157-176. [CrossRef]

55. Altinay, L.; Madanoglu, M.; Daniele, R.; Lashley, C. The influence of family tradition and psychological traits on entrepreneurial intention. Int. J. Hosp. Manag. 2012, 31, 489-499. [CrossRef]

56. Tang, J.; Tang, Z. The relationship of achievement motivation and risk-taking propensity to new venture performance: A test of the moderating effect of entrepreneurial munificence. Int. J. Entrep. Small Bus. 2007, 4, 450-472. [CrossRef]

57. Rotter, J.B. Generalized expectations for internal versus external control of reinforcement. Psychol. Monogr. Gen. Appl. 1966, 80, 1-28. [CrossRef]

58. Zimbardo, P.G. Psychology and Life; Scott, Foresman and Co.: Glenvie, IL, USA, 1985.

59. Allen, K.R. Launching New Ventures: An Entrepreneurial Approach, 4th ed.; Houghton Mifflin: New York, NY, USA, 2006.

60. Ajzen, I. Constructing a TpB Questionnaire: Conceptual and Methodological Considerations, 2002. Available online: http://www.uni-bielefeld.de/ikg/zick/ajzen\%20construction\%20a\%20tpb\%20questionnaire.pdf (accessed on 4 August 2016).

61. Collins, B.E. Four components of the Rotter Internal-External scale: Belief in a difficult world, a just world, a predictable world, and a politically responsive world. J. Pers. Soc. Psychol. 1974, 29, 381-391. [CrossRef] [PubMed]

62. Lefcourt, H.M. Locus of Control: Current Trends in Theory and Research; Erlbaum Associates: Hillsdale, MI, USA, 1976.

63. Schjoedt, L.; Shaver, K.G. Development and validation of a locus of control scale for the entrepreneurship domain. Small Bus. Econ. 2012, 39, 713-726. [CrossRef]

64. Liñán, F.; Urbano, D.; Guerrero, M. Regional variations in entrepreneurial cognitions: Start-up intentions of university students in Spain. Entrep. Reg. Dev. 2011, 23, 187-215. [CrossRef]

65. Nishantha, B. Influence of Personality Traits and Socio-demographic Background of Undergraduate Students on Motivation for Entrepreneurial Career: The Case of Sri Lanka. Ryukoku Univ. Dep. Bull. Pap. 2009, 29, 71-82.

66. Bae, T.J.; Qian, S.; Miao, C.; Fiet, J.O. The Relationship between Entrepreneurship Education and Entrepreneurial Intentions: A Meta-Analytic Review. Entrep. Theory Pract. 2014, 38, 217-254. [CrossRef]

67. Fayolle, A.; Gailly, B.; Lassas-Clerc, N. Assessing the impact of entrepreneurship education programmes: A new methodology. J. Eur. Ind. Train. 2006, 30, 701-720. [CrossRef]

68. Izquierdo, E.; Buelens, M. Competing models of entrepreneurial intentions: The influence of entrepreneurial self-efficacy and attitudes. Int. J. Entrep. Small Bus. 2011, 13, 75-91. [CrossRef] 
69. Nabi, G.; Walmsley, A.; Holden, R. Pushed or pulled? Exploring the factors underpinning graduate start-ups and non-start-ups. J. Educ. Work 2013, 28, 481-506. [CrossRef]

70. Skudiene, V.; Auruskeviciene, V.; Pundziene, A. Enhancing the Entrepreneurship Intentions of Undergraduate Business Students. Transform. Bus. Econ. 2010, 9, 472-489.

71. Martin, B.C.; McNally, J.J.; Kay, M.J. Examining the formation of human capital in entrepreneurship: A meta-analysis of entrepreneurship education outcomes. J. Bus. Ventur. 2013, 28, 211-224. [CrossRef]

72. Fayolle, A.; Gailly, B. The Impact of Entrepreneurship Education on Entrepreneurial Attitudes and Intention: Hysteresis and Persistence. J. Small Bus. Manag. 2015, 53, 75-93. [CrossRef]

73. Hisrich, R.D. A model for effective entrepreneurship education and research. In Entrepreneurship in Forschung und Lehre: Festschrift für Klaus Anderseck; Walterscheid, K., Ed.; Peter Lang: Frankfurt am Main, Germany, 2003; pp. 241-253.

74. Gasse, Y. A strategy for the promotion and identification of potential entrepreneurs at the secondary school level. In Frontiers of Entrepreneurship Research; Babson College: Wellesley, MA, USA, 1985; pp. 538-559.

75. Johansen, V.; Schanke, T. Entrepreneurship Education in Secondary Education and Training. Scand. J. Educ. Res. 2013, 57, 357-368. [CrossRef]

76. Do Paco, A.; Ferreira, J.; Raposo, M.; Rodrigues, R.G.; Dinis, A. Entrepreneurial intention among secondary students: Findings from Portugal. Int. J. Entrep. Small Bus. 2011, 13, 92-106. [CrossRef]

77. Gorman, G.; Hanlon, D.; King, W. Some Research Perspectives on Entrepreneurship Education, Enterprise Education and Education for Small Business Management: A Ten-Year Literature Review. Int. Small Bus. J. 1997, 15, 56-77. [CrossRef]

78. Matthews, C.H.; Moser, S.B. A Longitudinal Investigation of the Impact of Family Background and Gender on Interest in Small Firm Ownership. J. Small Bus. Manag. 1996, 34, $29-43$.

79. Kelley, D.J.; Singer, S.; Herrington, M.D. The Global Entrepreneurship Monitor: 2011 Global Report; Babson College: Wellesley, MA, USA, 2012.

80. Allen, I.E.; Elam, N.; Langowitz, N.; Dean, M. Global Entrepreneurship Monitor 2007 Report on Women and Entrepreneurship; Babson College and London Business School: Wellesley, MA, USA, 2008.

81. Shinnar, R.S.; Giacomin, O.; Janssen, F. Entrepreneurial Perceptions and Intentions: The Role of Gender and Culture. Entrep. Theory Pract. 2012, 36, 465-493. [CrossRef]

82. Chen, C.C.; Greene, P.G.; Crick, A. Does entrepreneurial self-efficacy distinguish entrepreneurs from managers? J. Bus. Ventur. 1998, 13, 295-316. [CrossRef]

83. BarNir, A.; Watson, W.E.; Hutchins, H.M. Mediation and Moderated Mediation in the Relationship among Role Models, Self-Efficacy, Entrepreneurial Career Intention, and Gender. J. Appl. Soc. Psychol. 2011, 41, 270-297. [CrossRef]

84. Becker, G.S. Investment in Human Capital: A Theoretical Analysis. J. Political Econ. 1962, 70, 9-49. [CrossRef]

85. Schultz, T.W. Investment in Human Capital. Am. Econ. Rev. 1961, 51, 1-17.

86. Wang, W.; Lu, W.; Kent, M.J. Determinants of Entrepreneurial Intention among College Students in China and USA. J. Glob. Entrep. Res. 2011, 1, 35-44.

87. Mueller, S.L.; Thomas, A.S. Culture and entrepreneurial potential: A nine country study of locus of control and innovativeness. J. Bus. Ventur. 2001, 16, 51-75. [CrossRef]

88. International Personality Item Pool. A Scientific Collaboratory for the Development of Advanced Measures of Personality Traits and Other Individual Differences, 2015. Available online: http:/ /ipip.ori.org/ (accessed on 4 August 2016).

89. Do, C.B.; Batzoglou, S. What is the expectation maximization algorithm? Nat. Biotechnol. 2008, 26, 897-899. [CrossRef] [PubMed]

90. Franco, M.; Haase, H.; Lautenschläger, A. Students' entrepreneurial intentions: An inter-regional comparison. Educ. Train. 2010, 52, 260-275. [CrossRef]

91. Kopycinska, D.; Bernat, T.; Korpysa, J. Researching students' entrepreneurship skills in post-socialist countries: A multi-country survey (Part 1). Transform. Bus. Econ. 2009, 8, 21-44.

92. Jaba, E.; Robu, I.B.; Balan, C.B.; Robu, M.A. Folosirea metodei ANOVA pentru obținerea probelor de audit $\mathrm{cu}$ privire la efectul domeniului de activitate asupra variației indicatorilor poziției și performanței financiare. Rev. Audit. Financ. 2012, 10, 3-12.

93. Jaba, E.; Robu, I.B. Obținerea probelor de audit pentru testarea Going Concern folosind metode statistice avansate în analiza influenței factorilor asupra ratei îndatorării globale. Rev. Audit. Financ. 2011, 9, 37-46. 
94. Field, A. Discovering Statistics Using SPSS, 2nd ed.; Sage Publications Ltd.: London, UK, 2005.

95. Lebart, L.; Piron, M.; Morineau, A. Statistique exploratoire multidimensionnelle. In Visualisation et Inférences en Fouille de Données, 4th ed.; Dunod: Paris, France, 2006.

96. Elzubeir, M.A.; Rizk, D.E.E. Identifying characteristics that students, interns and residents look for in their role models. Med. Educ. 2001, 35, 272-277. [CrossRef] [PubMed]

97. European Commission. Green paper-Entrepreneurship in Europe; DG Enterprise: Brussels, Belgium, 2003.

98. Liñán, F.; Rodríguez-Cohard, J.C.; Rueda-Cantuche, J. Factors affecting entrepreneurial intention levels: A role for education. Int. Entrep. Manag. J. 2011, 7, 195-218.

99. Baum, J.R.; Locke, E.A. The Relationship of Entrepreneurial Traits, Skill, and Motivation to Subsequent Venture Growth. J. Appl. Psychol. 2004, 89, 587-598. [CrossRef] [PubMed]

100. Zhao, H.; Seibert, S.E.; Hills, G.E. The Mediating Role of Self-Efficacy in the Development of Entrepreneurial Intentions. J. Appl. Psychol. 2005, 90, 1265-1272. [CrossRef] [PubMed]

(C) 2016 by the authors; licensee MDPI, Basel, Switzerland. This article is an open access article distributed under the terms and conditions of the Creative Commons Attribution (CC-BY) license (http://creativecommons.org/licenses/by/4.0/). 